\title{
Bacteria or microflagellates as a major food source for marine ciliates: possible implications for the microzooplankton*
}

\author{
Catherine Bernard, Fereidoun Rassoulzadegan \\ Université P. \& M. Curie (Paris VI), UA 716, Station Zoologique, B.P. 28, F-06230 Villefranche-sur-Mer, France
}

\begin{abstract}
Direct visual observations were made on the vacuole contents of the oligotrichous ciliate Strombidium cf. sulcatum fed 12 different types of food. These ranged in size from 0.6 to $11.9 \mu \mathrm{m}$ and included one fluorescently labelled bacterium, 2 types of cyanobacteria and 9 species of algae. We determined (i) the turnover time of food vacuoles as a function of prey quality and size, (ii) rates of grazing and filtration, and volume-specific clearance as a function of prey quality and size, (iii) the food concentration threshold for effective food intake in S. sulcatum when fed different types of prey, and (iv) an optimal particulate food size for $S$. sulcatum. Our results indicate the shortest feeding turnover time (13.7 $\pm 2.2 \mathrm{~min}$.) for $2.5 \mu \mathrm{m}$ prey (Nannochloris sp.). The average number of prey per vacuole and the feeding rate increased with food size to reach a maximum for this flagellate. Feeding efficiency then decreased to zero for particles within the size range 6.6 to $11.9 \mu \mathrm{m}$ (Platymonas sp., Hymenomonas elongata). Finally, it is shown that for food particle concentrations comparable to those of oligotrophic marine environments (e.g. 0.1 to $0.2 \mathrm{ppm}$ by volume) $S$. sulcatum depends on food particles measuring around $2.5 \mu \mathrm{m}$ for growth.
\end{abstract}

\section{INTRODUCTION}

Planktonic ciliates are believed to play a major role in marine food-webs. Depending on their body size, they ingest both pico- and nanoplankton in situ (Rassoulzagedan et al. 1988, and references therein). However, experimental data are necessary in order to further assess the role of food particle size selection.

Available data do not unambiguously show whether ciliate populations depend on the consumption of picoor nanoplankters since most work has been concerned only with the consumption of few types of food or inert particles. For instance data from Fenchel (1980a) and Jonsson (1986) suggest that oligotrichous ciliates (Polyhymenophora) are structurally adapted for the capture of microflagellates (food particles exceeding about 1 to $2 \mu \mathrm{m}$ in size), and are thus excluded from bacterivory in the open ocean. This hypothesis supports the idea that mainly zooflagellates constitute the efficient consumers of the bacterioplankton (Haas \& Webb 1979, Fenchel

\footnotetext{
- Contribution of the team Ecologie du Microzooplancton Marin
}

1982a to d, Sieburth 1984). Other studies, however, have demonstrated the occurrence of small planktonic oligotrichous ciliates in the sea (Rassoulzadegan \& Sheldon 1986, Sherr et al. 1986) which ingest bacteria more or less efficiently (Borsheim 1984, Rivier et al. 1985, Lessard \& Swift 1985, Sherr \& Sherr 1987).

In an attempt to clarify this we here present the results of experiments on feeding rates and turnover times in a medium sized oligotrichous ciliate, Strombidium sulcatum, capable of growing on bacteria as well as on flagellates in the laboratory (Rivier et al. 1985, Fenchel \& Jonsson 1988, Sherr et al. 1988). This ciliate was fed on different kinds of pico- and nanoplanktonic preys; thus we determined the optimum food particle size using natural food items. We then discuss the possible implications of our experimental results for smaller ( $\leq 20 \mu \mathrm{m}$ ) planktonic ciliates.

\section{MATERIAL AND METHODS}

Three series of experiments (Expts 1 to 3 ) were carried out in order to investigate the feeding behaviour of the oligotrichous ciliate Strombidium sulcatum (Clap. \& 
Lachm.). Stock populations of S. sulcatum were maintained in wheat grain cultures (Rivier et al. 1985), and cyanobacteria and autotrophic flagellates were grown in Guillard's f/2 (Guillard 1975) culture medium. In order to obtain ciliates with vacuoles relatively free of bacteria, they were kept in natural seawater for 4 to $5 \mathrm{~d}$ prior to experiments.

In the first 2 series of experiments, ciliate and prey densities were adjusted so that experiments were always initiated with 11 ciliates $\mathrm{ml}^{-1}$ and $4.9 \times 10^{5} \mu^{3}$ $\mathrm{ml}^{-1}$ ( $0.5 \mathrm{ppm}$ by volume) of food (either bacteria or autotrophic flagellates). For microscope observations the samples were fixed with borax-buffered formalin at $2 \% \mathrm{v} / \mathrm{v}$ final concentration (Steedman 1976). To adjust the initial ciliate and prey concentrations, cultures were examined by Utermöhl and epifluorescence microscopy (Utermöhl 1931, Hobbie et al. 1977), according to Rassoulzadegan \& Gostan (1976), Davis \& Sieburth (1982), and Sherr et al. (1988), for ciliates, plastidic flagellates, and fluorescently labelled bacteria (FLB), respectively. The third set of experiments investigated the influence of different prey concentrations on feeding rates of Strombidium sulcatum at the same initial concentration of ciliates ( 11 cells $\mathrm{ml}^{-1}$ ).

Expt 1 dealt with the kinetics of food accumulation in the vacuoles of ciliates fed with 5 different types of bacterial and algal prey. These were a $0.6 \mu \mathrm{m}$ FLB (Sherr et al. 1987), a $1.0 \mu \mathrm{m}$ cyanobacterium (Synechococcus sp.), and 3 autotrophic flagellates (Nannochloris sp., $2.5 \mu \mathrm{m}$, Emiliania huxleyi, $4.1 \mu \mathrm{m}$, Isochrysis galbana, $5.5 \mu \mathrm{m}$; Table 1). The food vacuole contents of ciliates were studied by examining 20 ciliates at intervals of 5 to $10 \mathrm{~min}$ during 145 to $150 \mathrm{~min}$ incubations by epifluorescence microscopy following the method of Rassoulzadegan et al. (1988). This method takes into account those vacuoles contents (few \% in ciliates) split up by fixation (Sieracki et al. 1987), which remain as compact items attached to the anterior part of the cells, and which are easily distinguished from extraneous materials.
Data were fitted to an Ivlev model:

$$
\mathrm{r}=\mathrm{p}\left[1-\mathrm{e}^{(-\mathrm{k} t)}\right]
$$

where $r=$ food vacuole content $\left(\mu \mathrm{m}^{3}\right) ; \mathrm{p}=$ asymptotic, steady state value for $\mathrm{r}(\mathrm{r}(\mathrm{t} \rightarrow \infty)) ; \mathrm{k}=\mathrm{a}$ constant $\left(\mathrm{t}^{-1}\right)$; and $\mathrm{t}=$ incubation time $(\mathrm{min})$. The relationships were all significant (F-test) at the $1 \%$ level.

The food turnover time (FTT, min) is equivalent to $\mathrm{p} /$ $\mathrm{kp}(\mathrm{kp}=$ initial slope of the vacuole volume-time curve, $\mu \mathrm{m}^{3} \mathrm{~min}^{-1}$ ) or to $1 / \mathrm{k}$.

Expt 2 was designed to determine the maximum volume of ciliate food vacuole contents for 12 different prey species varying in size from 0.6 to $11.9 \mu \mathrm{m}$ (Table 2). Only one sample was taken after $150 \mathrm{~min}$ of incubation, and 20 ciliates were examined for each prey. This incubation time was sufficient to determine the steady state value of vacuole content since the average food turnover time for Strombidium sulcatum was less than $24 \min$ (Table 1 ).

In Expt 3 we compared the functional response of Strombidium sulcatum using FLB, Synechococcus sp., Nannochloris sp. and 2 larger algae, Monochrysis lutheri and Dunaliella minuta. Twenty ciliate individuals were examined for each prey and for each food concentration. In order to compare feeding rates on prey of different sizes, feeding rates were expressed as volume-specific grazing (VSG, ciliate volumes $\mathrm{h}^{-1}$ ). Data were fitted to a Michaelis-Menten model:

$$
\mathrm{VSG}=\mathrm{VSG}_{\max }(\mathrm{S}-\mathrm{b}) /\left(\mathrm{k}_{\mathrm{VSG}}+(\mathrm{S}-\mathrm{b})\right)
$$

where $\mathrm{VSG}_{\max }=$ maximum volume-specific grazing (volumes $\left.\mathrm{h}^{-1}\right) ; \mathrm{S}=$ the particle food concentration $\left(\mu \mathrm{m}^{3}\right.$ $\left.\mathrm{ml}^{-1}\right) ; \mathrm{b}=$ theoretical abscissa value for VSG $=0$; and $\mathrm{K}_{\mathrm{VSG}}=$ the half-saturation constant (food concentration for $\mathrm{VSG}=\mathrm{VSG}_{\max } / 2$ ). The relationships were all significant (F-test) at the $1 \%$ level.

\section{RESULTS}

Fig. 1 shows that Strombidium sulcatum ingests different bacterial and algal prey at different rates.

Table 1. Strombidium sulcatum. Parameters of feeding from data fitted to the Ivlev model $\left(\mathrm{r}=\mathrm{p}\left[1-\mathrm{e}^{(-\mathrm{kt})}\right]\right)$. $\mathrm{p}: \mathrm{steady}$ state food vacuole volume; $\mathrm{k}$ : constant

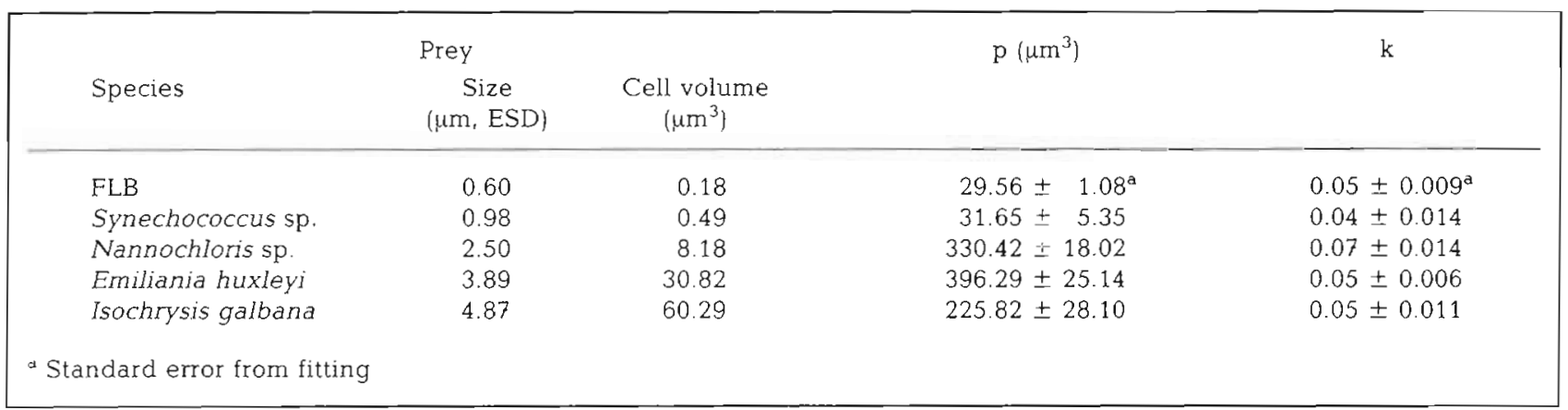


Fig. 1. Strombidium sulcatum. Kinetics of the vacuole content packaging in an oligotrichous ciliate, fed with different bacterial and autotrophic flagellate food resources. Changes in the food intake time series were fitted to an Ivlev model (see 'Material and methods'). Error bars represent 20 observations (individuals) at each time interval

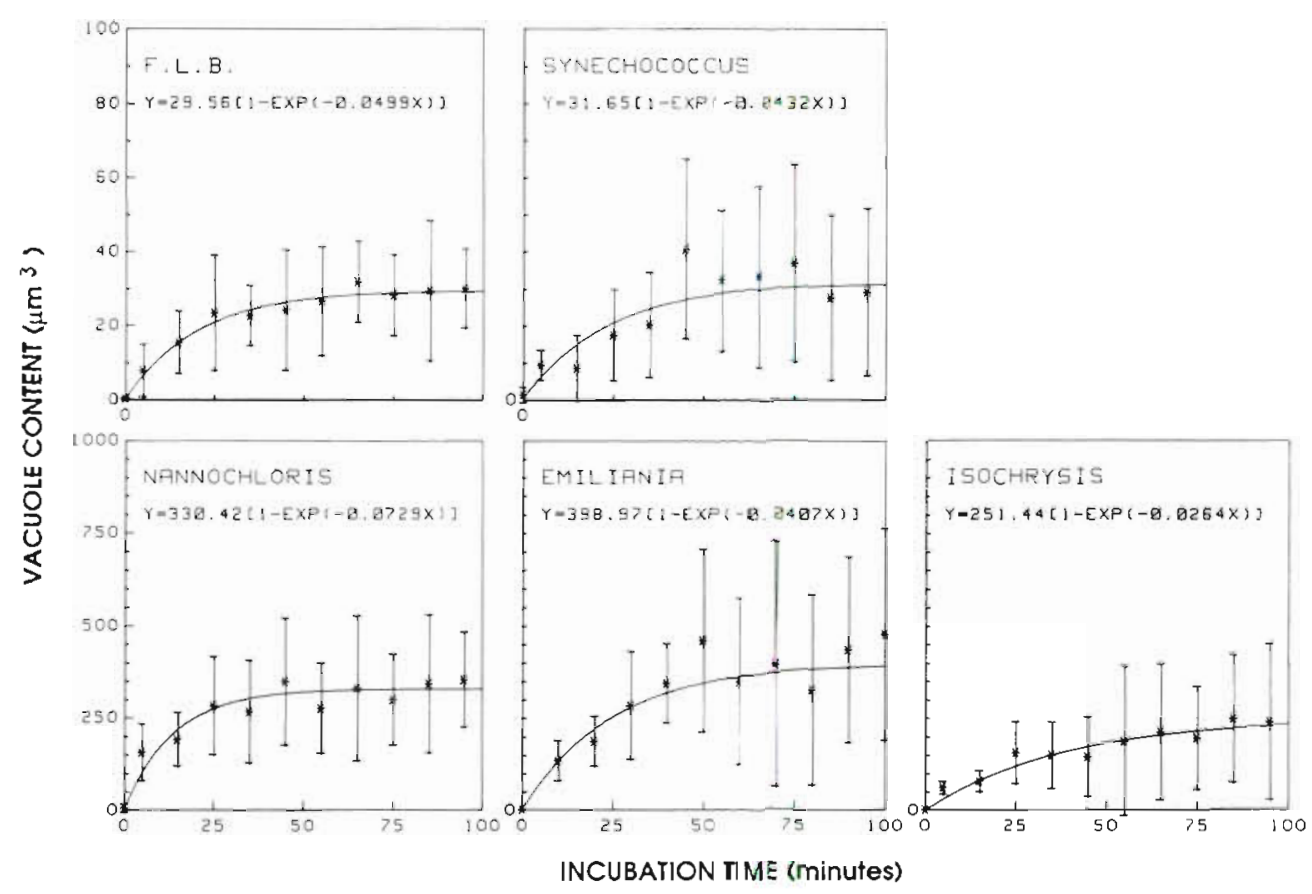

Table 1 gives data for parameters calculated from Eq. (1). Values of p varied from $29.6 \mu \mathrm{m}^{3}$ (FLB) to $396.3 \mu \mathrm{m}^{3}$ (Emiliania huxleyi). In general, the average value observed for algae $\left(202.8 \mathrm{\mu m}^{3}\right)$ was almost an order of magnitude higher than that observed for bacteria $\left(30.6 \mu \mathrm{m}^{3}\right)$.

Fig. 2 shows that the lowest feeding turnover time (FTT) was obtained for the $2.5 \mu \mathrm{m}$ flagellate Nannochloris sp. (13.7 \pm (SE) $2.2 \mathrm{~min})$. Values were comparable for other preys $(20.1 \pm 3.1,23.1 \pm 6.0,21.4 \pm 2.6$, $20.1 \pm 3.7$ min, for FLB, Synechococcus sp., Emiliania huxleyi, and Isochrysis galbana, respectively).

Expt 2 was concerned with a comparison of the observed maximum value for food vacuole packaging after 150 min incubation for 14 bacterial and algal prey

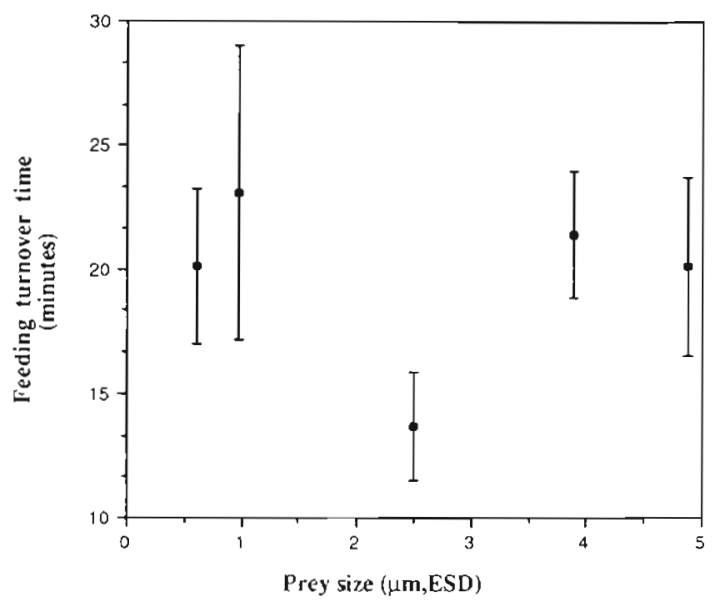

Fig. 2. Strombidium sulcatum. Relationship between feeding turnover time and prey size in the 0.6 to $11.9 \mu \mathrm{m}$ size range (Fig. 3). Except for the largest algae used (Platymonas sp., $6.6 \mu \mathrm{m}$, and Hymenomonas sp., $11.9 \mu \mathrm{m})$ which were not ingested at all, results yielded a minimum value $\left(83 \pm 49 \mu^{3}\right)$ for bacteria and a maximum value $\left(715 \pm 271 \mu^{3}\right)$ for Nannochloris sp. (Table 2). However, at sizes $>2.5 \mu \mathrm{m}$ (Nannochloris sp.) vacuole steady state values gradually decreased with increasing prey size.

On the basis of values of feeding turnover times (Expt 1), we calculated rates of feeding, filtering, and volume-specific clearance for the different food particle sizes (Table 2). Results show that Strombidium sulcatum ingested bacteria at rates varying from 174 to 283 (average 229) $\mu \mathrm{m}^{3}$ ciliate $^{-1} \mathrm{~h}^{-1}$ (clearance 0.4 to $0.6 \mu \mathrm{l}$ ciliate ${ }^{-1} \mathrm{~h}^{-1}$ ) and algae at rates from 831 to 3125 (average $1978{\text { ) } \mathrm{m}^{3} \text { ciliate }}^{-1} \mathrm{~h}^{-1}$ (clearance 1.7 to $6.4 \mu \mathrm{l}$ ciliate $\left.{ }^{-1} \mathrm{~h}^{-1}\right)$. In terms of volume-specific clearance these values correspond to 36 to $58 \times 10^{3}$ (average $47 \times$ $10^{3}$ ) body volumes $\mathrm{h}^{-1}$ when feeding on bacteria and 170 to $638 \times 10^{3}$ (average $404 \times 10^{3}$ ) body volumes $\mathrm{h}^{-1}$ when ingesting algae. Nannochloris sp. $(2.5 \mu \mathrm{m})$ yielded the highest value (Table 2).

Functional responses of Strombidium sulcatum for different concentrations offered of bacterial foods (FLB, Synechococcus) and 3 algae $\geq 2.5 \mu \mathrm{m}$ in diameter are shown in Fig. 4. Average values calculated from Eq. (2) show that, for food in the 1.0 to $4.2 \mu \mathrm{m}$ size range, $\mathrm{K}_{\mathrm{VSG}}$ varied from $4.1 \times 10^{4} \mathrm{um}^{3} \mathrm{ml}^{-1}$ (ca $0.04 \mathrm{ppm}$ ) for Nannochloris sp. to $45.3 \times 10^{4} \mu^{3} \mathrm{ml}^{-1}$ (ca $0.45 \mathrm{ppm}$ ) for Monochrysis sp., whereas for heterotrophic bacteria (FLB, $0.6 \mu \mathrm{m}$ ) it was about $161.9 \times 10^{4} \mu^{3} \mathrm{ml}^{-1}$ (ca $1.60 \mathrm{ppm})$, and averaged about $65.5 \times 10^{4} \mu^{3} \mathrm{ml}^{-1}$ (ca $0.65 \mathrm{ppm}$ ) for $>4 \mu \mathrm{m}$ algae Dunaliella minuta 


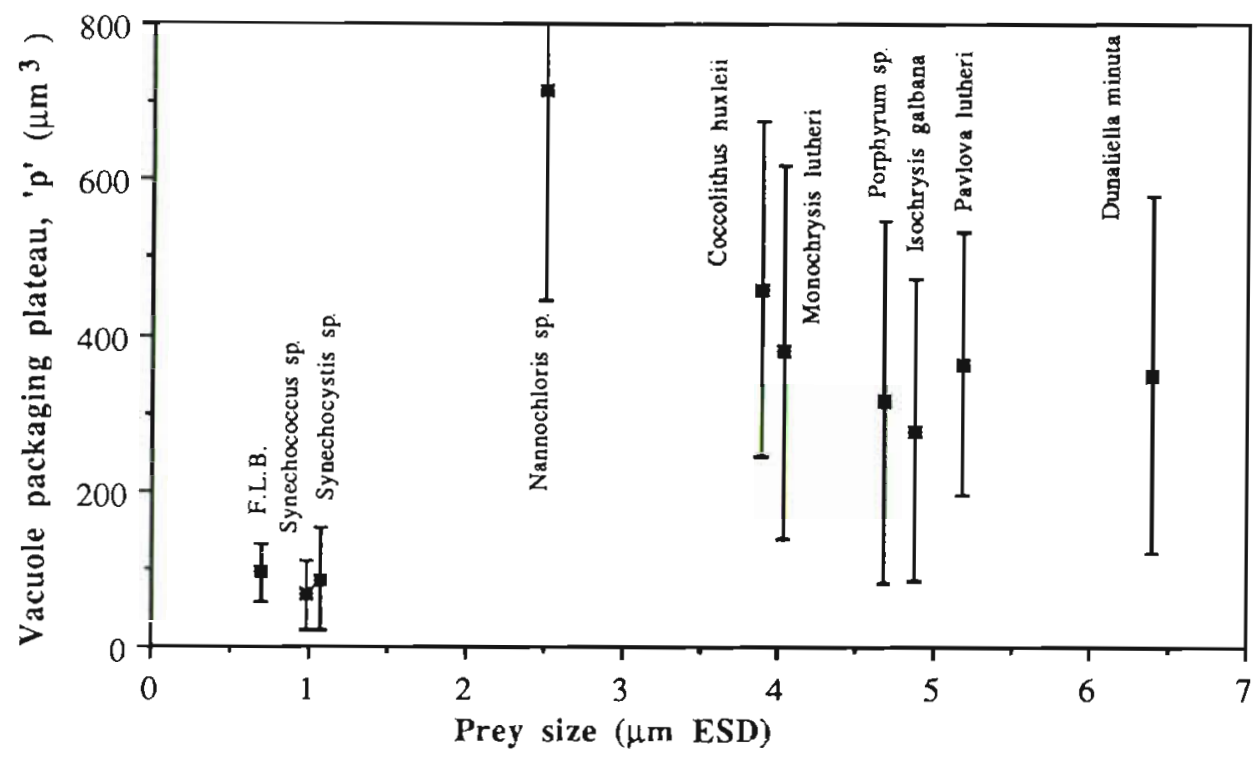

Fig. 3. Strombidium sulcatum. Relationship between food vacuole packaging plateau and different bacterial and algal prey items in the 0.60 to 11.85 size range. Error bars represent 20 observations (individuals) at each time interval

(Table 3). Values for maximum volume-specific grazing $\left(V_{S G} G_{\max }\right)$, calculated from Eq. (2), for algal food (15.1 to $48.1 \times 10^{-2}$ volumes $\mathrm{h}^{-1}$; Table 3) were more than an order of magnitude higher than those estimated for either bacterial or cyanobacterial food 10.9 to $1.9 \times 10^{-2}$ volumes $h^{-1}$ ). Fig. 5 shows that among the values for half-saturation constant calculated from Eq. (2), only that for the $2.5 \mu \mathrm{m}$ prey (Nannochloris sp.) was within the concentration range usually found in oligotrophic marine environments ( $\leq 0.25 \mathrm{ppm}$ ).

\section{DISCUSSION}

Phagotrophy in planktonic ciliated protozoa, especially oligotrichs, seems to be a major pathway in the carbon flow from the microbial loop to higher trophic levels, that is, zooplankton (Azam et al. 1983, Wiadnyana \& Rassoulzadegan 1989), and this role becomes even more crucial when primary production is dominated by picoplankton (Hagström et al, 1988).

Particulate food size range and feeding rates in marine oligotrichous ciliates have been previously investigated (Rassoulzagedan 1978, 1982, Heinbokel \& Beers 1979, Capriulo \& Carpenter 1980, 1983, Fenchel 1980a, Rassoulzadegan \& Etienne 1981, Stoecker et al. 1981). These studies lead to the conclusion that $\leq$ $200 \mu \mathrm{m}$ microzooplanktonic ciliates can control the nanoplanktonic production in the sea (Verity $1989 \mathrm{a}, \mathrm{b}$ ). However, some small ( $\leq 20 \mu \mathrm{m}$ ) planktonic oligo-

Table 2. Strombidium sulcatum. Maximum food vacuole contents (VC), and estimate of ingestion and filtration rates ( $I, F)$, and of volume-specific clearance (VSC) in ciliates fed on different bacterial and algal preys during 150 min incubation

\begin{tabular}{|c|c|c|c|c|c|c|}
\hline Species & $\begin{array}{l}\text { Size } \\
(\mu \mathrm{m}, \mathrm{ESD})\end{array}$ & $\begin{array}{l}\text { Cell volume } \\
\qquad\left(\mu \mathrm{m}^{3}\right)\end{array}$ & $\begin{array}{c}\text { VC } \\
\left(\mu \mathrm{m}^{3} \text { vacuole }^{-1}\right)\end{array}$ & $\left(\mu \mathrm{m}^{3}\right.$ ciliate $\left.^{-1} \mathrm{~h}^{-1}\right)$ & $\left(\mu \mathrm{l}\right.$ ciliate $\left.\mathrm{F}^{-1} \mathrm{~h}^{-1}\right)$ & $\begin{array}{c}\text { VSC }^{\mathrm{a}} \\
\left(\times 10^{5} \text { vol. } \mathrm{h}^{-1}\right)\end{array}$ \\
\hline FLB & 0.60 & 0.18 & $95.04 \pm 37.17^{6}$ & 283.41 & 0.58 & 0.58 \\
\hline Synechococcus sp. & 0.98 & 0.49 & $67.08 \pm 44.42$ & 174.27 & 0.36 & 0.36 \\
\hline Synechocystis sp. & 1.08 & 0.67 & $86.89 \pm 66.03$ & 225.22 & 0.46 & 0.46 \\
\hline Nannochloris sp. & 2.50 & 8.18 & $714.52 \pm 271.00$ & 3125.31 & 6.38 & 6.38 \\
\hline Emiliania huxleyi & 3.89 & 30.82 & $460.24 \pm 214.03$ & 1289.59 & 2.63 & 2.63 \\
\hline Monochrysis lutheri & 4.02 & 34.12 & $378.73 \pm 241.57$ & $1129.37^{c}$ & $2.30^{\mathrm{c}}$ & $2.30^{c}$ \\
\hline Prophyridium cruentum & 4.68 & 53.84 & $314.96 \pm 233.13$ & $939.21^{c}$ & $1.92^{c}$ & $1.92^{c}$ \\
\hline Isochrysis galbana & 4.87 & 60.29 & $278.56 \pm 192.78$ & 830.67 & 1.70 & 1.70 \\
\hline Pavlova lutheri & 5.18 & 72.77 & $363.85 \pm 168.83$ & $1058.00^{\mathrm{c}}$ & $2.21^{c}$ & $2.21^{c}$ \\
\hline Dunaliella minuta & 6.40 & 140.00 & $350.00 \pm 228.20$ & $1043.70^{c}$ & $2.13^{c}$ & $2.13^{c}$ \\
\hline Platymonas sp. & 6.55 & 147.14 & no ingestion & - & - & - \\
\hline Hymenomonas elongata & 11.85 & 871.27 & no ingestion & - & - & - \\
\hline
\end{tabular}


Fig. 4. Strombidium sulcatum. Kinetics of volumespecific grazing as a function of food concentrations for different bacterial and algal prey items: (A) $0.60 \mu \mathrm{m} \mathrm{FLB}$; (B) $0.98 \mu \mathrm{m}$ Synechococcus sp.; (C) $2.50 \mu \mathrm{m}$ Nannochloris sp.; (D) $4.02 \mu \mathrm{m}$ Monochrysis sp.; (E) $6.40 \mu \mathrm{m}$ Dunaliella sp. Changes in the food intake time series were fitted to a Michaelis-Menten model (see Material and methods'). Error bars represent 20 observations (individuals) at each time interval

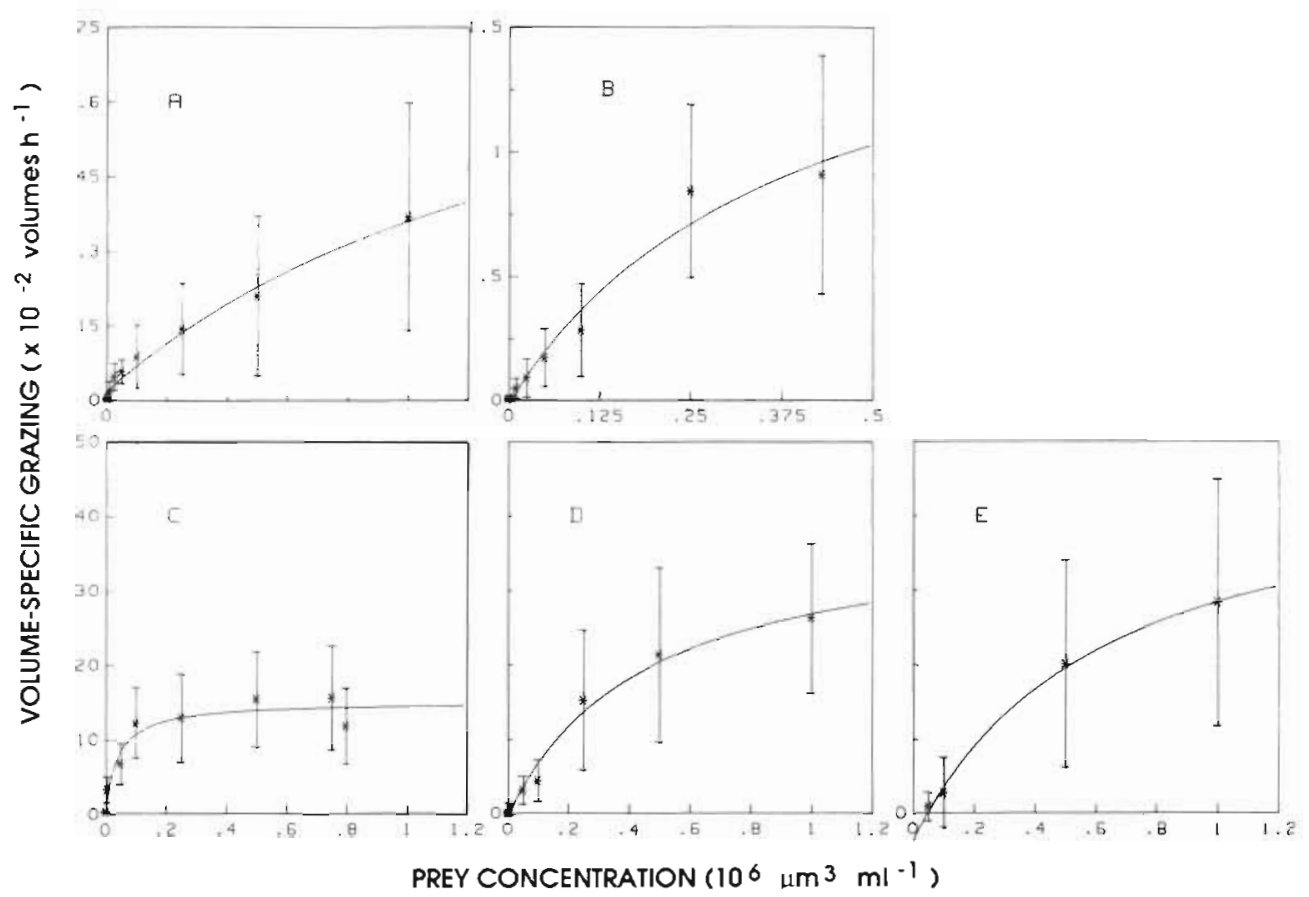

trichous ciliates may ingest bacterioplankton (Børsheim 1984, Rivier et al. 1985, Lessard \& Swift 1985, Sherr et al. 1987, 1989, Sherr \& Sherr 1987). Nevertheless, we need appropriate approaches allowing us to compare prey size partition in marine ciliates (Jonsson 1986, Verity \& Villareal 1986).

The method used here to quantify feeding parameters is simple and enables the in vivo food vacuole content to be examined either by autofluorescence in the case of algae (Rassoulzadegan et al. 1988) or by induced fluorescence (FLB, Sherr et al. 1987, 1988) using epifluorescence microscopy. The natural fluorescence of the photosynthetic pigments in autotrophic flagellates and other algae allowed us to study food accumulation in vacuoles for living and motile prey, without artificial preparation of food particles. Since protozoa may possess mechanoreceptors (Naitoh \& Eckert 1974) as well as chemoreceptors (Van Houten et al. 1975, Buskey \& Stoecker 1988, Fenchel \& Jonsson 1988), inert particles may lead to altered behavioural responses. In addition, for a slow-moving predator, immobilized prey may underestimate capture rate (Gerritsen \& Strickler 1977).

The oligotrichous ciliate we used here (Strombidium sulcatum) may not totally represent planktonic forms (Fenchel 1986), but can be considered as a model with respect to filter-feeding in Polyhymenophoran. The analysis of ca 5000 individuals of $S$. sulcatum allowed us to draw conclusions about feeding efficiency as a combined function of food particle size and concen-

Table 3. Strombidium sulcatum. Parameters of food-concentration-dependent feeding from data fitted to the Michaelis model: IVSG $\left.=V_{\text {VSG }}(\mathrm{S}-\mathrm{b}) /\left(\mathrm{k}_{\mathrm{VsG}}+\mathrm{S}-\mathrm{b}\right)\right]_{;}$VSG $_{\max }$ : maximum volume-specific grazing; $\mathrm{S}$ : food concentration; b: theoretical absciss value for $\mathrm{VSG}=0 ; \mathrm{k}_{\mathrm{VSG}}$ : half-saturation constant

\begin{tabular}{|c|c|c|c|}
\hline Prey & $\begin{array}{c}\text { VSG }_{\max }{ }^{a} \\
\left(\times 10^{-2} \text { vol. }^{-1}\right)\end{array}$ & $\begin{array}{c}\mathrm{b} \\
\left(\times 10^{3} \mu \mathrm{m}^{3} \mathrm{ml}^{-1}\right)\end{array}$ & $\frac{\mathrm{k}_{\mathrm{VSG}}}{\left(\times 10^{3} \mu \mathrm{m}^{3} \mathrm{ml}^{-1}\right)}$ \\
\hline FLB & $0.9 \pm 0.3^{b}$ & $-30.7 \pm 19.0^{b}$ & $1619.2 \pm 837.3^{b}$ \\
\hline Synechococcus sp. & $1.9 \pm 0.5$ & $3.2 \pm 7.0$ & $393.7 \pm 205.7$ \\
\hline Nannochloris sp. & $15.1 \pm 1.2$ & $-1.2 \pm 3.5$ & $41.2 \pm 19.8$ \\
\hline Monochrysis sp. & $39.1 \pm 4.7^{\mathrm{c}}$ & $4.4 \pm 8.6$ & $453.9 \pm 124.7$ \\
\hline Dunaliella sp. & $48.1 \pm 8.4^{\circ}$ & $47.1 \pm 13.4$ & $655.4 \pm 246.7$ \\
\hline \multicolumn{4}{|c|}{$\begin{array}{l}\text { Based on ciliate cell volume }=10^{4} \mathrm{~mm}^{3} \text {, and on the feeding turnover time estimates according to fitting to the Ivlev model in } \\
\text { Expt } 1 \\
\text { b Standard error from fitting } \\
\text { C Based on feeding turnover time estimated for Isochrysis galbana (see Table 1) }\end{array}$} \\
\hline
\end{tabular}


tration. The ciliate feeds effectively on prey ranging in size from 0.6 to $6.6 \mu \mathrm{m}$, but was most efficient for prey in the $2.5 \mu \mathrm{m}$ size range (e.g. Nannochloris sp.). Indeed, our data indicated that, for a given food concentration (0.49 ppm by volume), an oligotrichous ciliate of ca $30 \mu \mathrm{m}$ can ingest algae at rates more than an order of magnitude higher than it can ingest bacteria (range = $174.3 \mu \mathrm{m}^{3}$ Synechococcus ciliate ${ }^{-1} \mathrm{~h}^{-1}$ to $3125.3 \mu \mathrm{m}^{3}$ Nannochloris ciliate $\left.{ }^{-1} \mathrm{~h}^{-1}\right)$, and prey size seems to be a major factor (Table 2).

Any consideration of the role of food particle size spectrum must take into account the in situ concentrations of the different size classes. In oligotrophic waters, the total microbial $(0.3$ to $20 \mu \mathrm{m}$ size range) particulate content is about $0.25 \mathrm{ppm}$ by volume (Sheldon et al. 1972), which approximately corresponds to a total of $5 \times 10^{5}$ to $10^{6}$ bacteria ml $\mathrm{ml}^{-1}, 5 \times 10^{2}$ to $10^{3}$ flagellates $\mathrm{ml}^{-1}$, and 1 ciliate $\mathrm{ml}^{-1}$. The data for volume-specific grazing (hourly ingestion/ciliate body volume ratio, volumes $h^{-1}$ ) showed that even at food concentration levels as high as that of eutrophic environments (e.g. 1.0 ppm; Sheldon et al. 1972) Strombidium sulcatum could only accumulate bacterial ( $\leq 0.6 \mu \mathrm{m}$ ) food at maximum rates corresponding to about $2 \%$ of its body weight per day (Table 3 ). Indeed, Rivier et al. (1985) have shown that this ciliate can grow on $0.6 \mu \mathrm{m}$ bacteria when concentrations reach ca $10^{7}$ bacteria $\mathrm{ml}^{-1}$. Fenchel \& Jonsson (1988) reached a similar conclusion. Sherr \& Sherr (1987) have also shown that in nutrient-rich estuarine waters, some species of oligotrichous ciliates can ingest bacteria at high rates. This is consistent with our demonstration (Table 3, Fig. 5) that for this ciliate, the half-saturation constant for bacterial size, calculated from Eq. (2), was about $1.6 \mathrm{ppm}$, which corresponds to particle concentrations

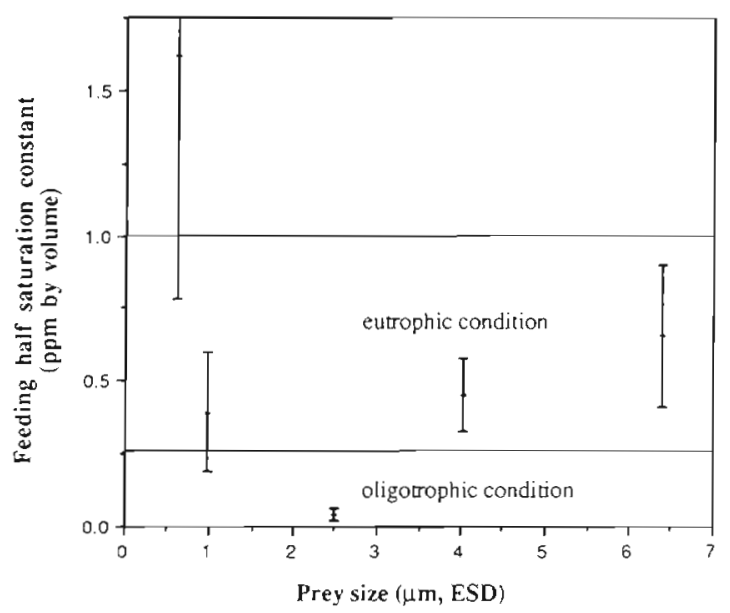

Fig. 5. Strombidium sulcatum. Relationship between the feeding half-saturation constant and the size of prey offered. Horizontal bars indicate the approximate upper limits for oligo- and eutrophic food concentration levels in marine environments in very eutrophic marine environments (Sheldon et al. 1972). With respect to algal size we found that only for a $2.5 \mu \mathrm{m}$ prey does this constant vary within the oligotrophic food concentration range (Fig. 5). It would therefore seem that by feeding on algae the ciliate can cover its growth needs, even at relatively low food concentrations. Fenchel \& Jonsson (1988) suggested a gross growth efficiency of 0.5 for this ciliate. On this basis, and according to the ingestion rate values obtained at $0.25 \mathrm{ppm}$ food concentration, we estimated a generation time of about $16 \mathrm{~h}$ for a Strombidium sulcatum feeding on Nannochloris sp. These results suggest that, in the natural environment, a ca $30 \mu \mathrm{m}$ oligotrichous ciliate is likely adapted to ingest prey at size around $2 \mu \mathrm{m}$.

The potential of small oligotrichous ciliates to ingest free-living bacteria has been suggested earlier (Ibanez \& Rassoulzadegan 1977, Rassoulzadegan 1982). From time to time, a significant proportion of the oligotrichous ciliates in the open ocean are comprised of small $(<20 \mu \mathrm{m})$ species (Rassoulzadegan \& Sheldon 1986, Sherr et al. 1986). On the basis of data we collected on the naturally occuring grazing size spectra in major Mediterranean tintinnid species in the 1970 s (see Rassoulzadegan et al. 1988 for spectra), and of this study, we can estimate the theoretical optimal food size for these small ciliates. By calculating a regression from a rough linear relationship between oligotrich cell volumes and their natural food sizes (Fig. 6), we obtained a hypothetical prey average (average of whole grazing spectrum for each species) and modal size (size within spectra for which grazing rates were maximum) of roughly 2.2 and $0.6 \mu \mathrm{m}$, respectively, for a $12 \mu \mathrm{m}$ oligotrichous ciliate. Thus it seems that even the smallest ciliates would ingest only bacteria larger than the average size that occurs naturally $(0.5 \mu \mathrm{m}$; McManus \& Fuhrman 1986). Although these small forms can ingest large heterotrophic bacteria (Sherr et al. 1989), it would seem that they are better adapted to feed on both cyanobacteria and picoplanktonic eukaryotes, as was suggested by Fenchel (1980c), and recently demonstrated by Rassoulzadegan et al. (1988).

Our observations agree with earlier studies suggesting that the polyhymenophoran feeding structure is not adapted to an efficient utilization of naturally occurring bacterial food sources (Fenchel 1980a), and this group consequently cannot depend on bacterivory in the open ocean (Fenchel 1980b).

A general conclusion regarding the trophic role of planktonic oligotrichs is that the smallest ones $1 \leq 20$ $\mu \mathrm{m}$ ) are likely consumers of the assemblage of large heterotrophic bacteria (Sherr et al. 1990) and cyanobacteria, whereas the middle-sized ones (30 to $50 \mu \mathrm{m}$ ) seem to be adapted to ingest $\leq 3$ to $4 \mu \mathrm{m}$ algae for food. In this way ciliates may control the 2 populations of 


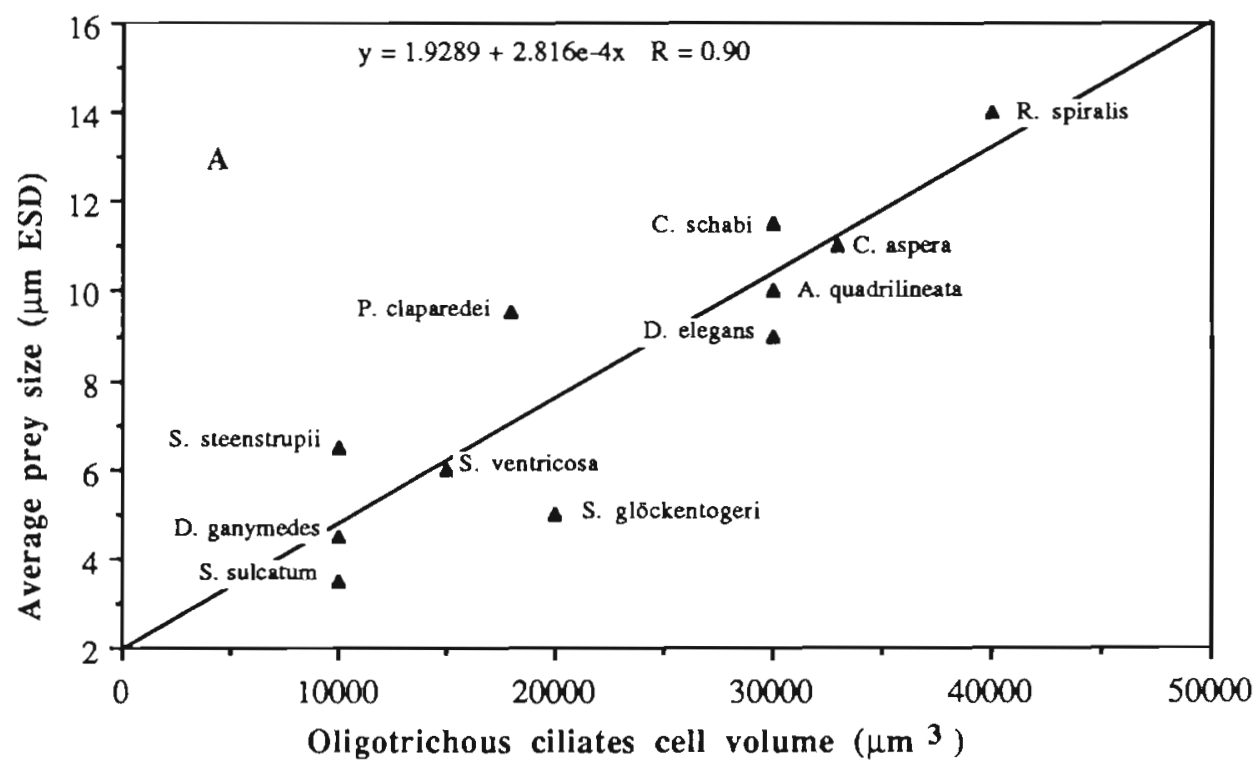

Fig. 6. Relationship between (A) average and (B) modal prey size and major Mediterranean oligotrichous ciliates species (tintinnids and naked forms, see text) size range. Estimated slopes are highly significant. The scatter of points (standard error $=16$ and $24 \%$ at $\mathrm{p}=95 \%$ for $\mathrm{A}$ and $\mathrm{B}$, respectively) indicates interspecific variability

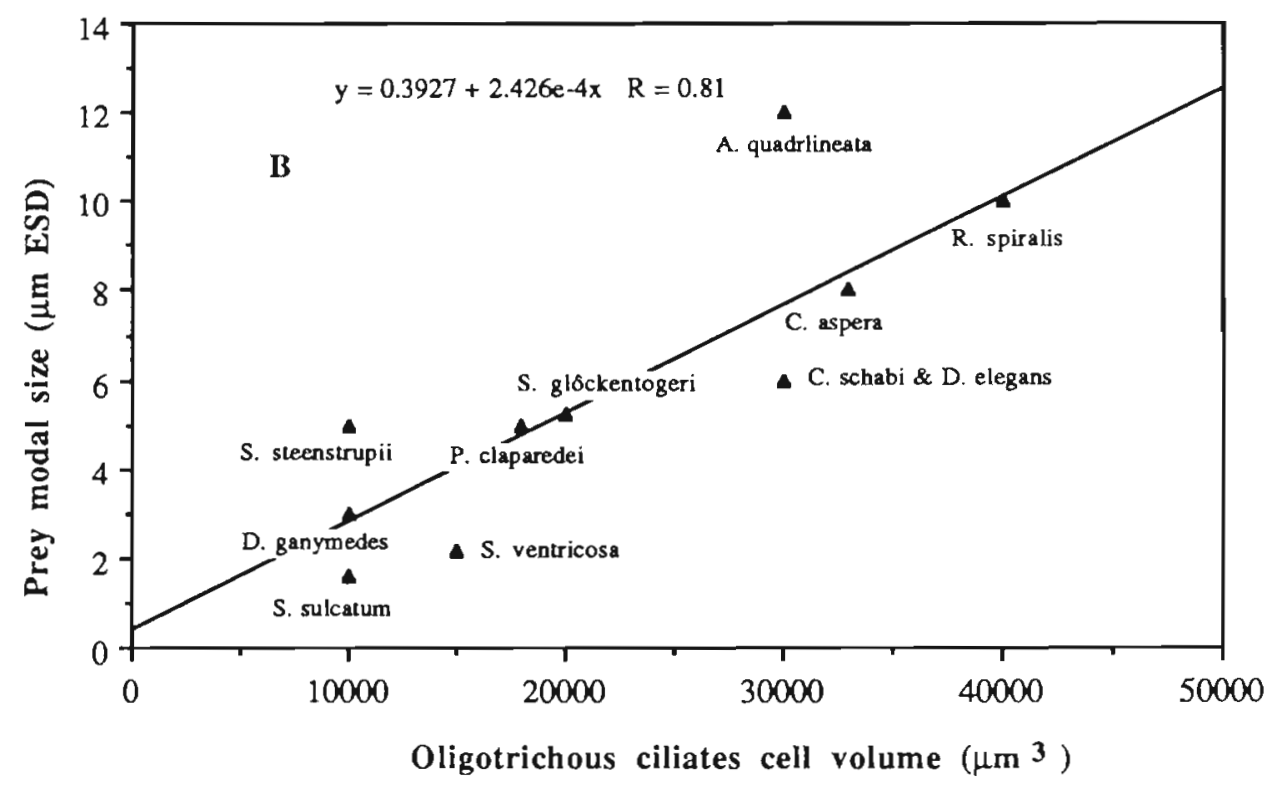

primary producers that dominate oligotrophic manine environments.

Acknowledgements. We thank Ev and Barry Sherr for providing fluorescently labelled bacteria, and 2 anonymous referees for constructive comments. Tom Fenchel and Ray Sheldon kindly corrected the initial version of the manuscript. Michèle Etienne assisted in the computation of the data. As a part of C. B.'s Ph. D., this research was supported by CNRS/INSU, GDRP4, FMO-DYFAMED, and UA 716 grants.

\section{LITERATURE CITED}

Azam, F., Fenchel, T., Field, J. G., Gray, J. S., Meyer-Reil, L.A., Thingstad, F. (1983). The ecological role of water column microbes in the sea. Mar. Ecol. Prog. Ser. 10: 257-263
Børsheim, K. Y. (1984). Clearance rates of bacteria-sized particles by freshwater ciliates, measured with monodisperse fluorescent latex beads. Oecologia (Berl.) 63: 286-288

Buskey, E. J., Stoecker, D. K. (1988). Locomotory patterns of the planktonic ciliate Favella sp.: adaptation for locating food patches and food particles. Bull. mar. Sci. 43: $783-796$

Capriulo, G. M., Carpenter, E. J. (1980). Grazing by 35 to $202 \mu \mathrm{m}$ microzooplankton in Long Island Sound. Mar. Biol. 56: $319-326$

Capriulo, G. M., Carpenter, E. J. (1983). Abundance, species composition, and feeding impact of tintinnid microzooplankton in central Long Island Sound. Mar. Ecol. Prog. Ser. 10: 277-288

Davis, P. G., Sieburth, J. McN. (1982). Differentiation of photo- 
trophic and heterotrophic nanoplankton populations in marine waters by epifluorescence microscopy. Annls Inst. océanogr., Paris 58 (S): 249-260

Fenchel, T. (1980a). Suspension feeding in ciliated protozoa: structure and function of feeding organelles. Arch. Protistenk. 123: 239-260

Fenchel, T (1980b). Relation between particle size selection and clearance in slispension feeding ciliates. Limnol. Oceanogr. 25: 735-740

Fenchel, T., (1980c). Suspension feeding in ciliated protozoa: functional response and particle size selection. Microb. Ecol. 6: 1-12

Fenchel, T. (1982a). Ecology of heterotrophic microflagellates. I. Some important forms and their functional morphology. Mar. Ecol. Prog. Ser. 8: 211-223

Fenchel, T. (1982b). Ecology of heterotrophic microflagellates. II. Bioenergetics and growth. Mar. Ecol. Prog. Ser. 8: 225-231

Fenchel, T (1982c). Ecology of heterotrophic microflagellates. III. Adaptations to heterogeneous environments. Mar. Ecol. Prog. Ser. 9: 25-33

Fenchel, T. (1982d). Ecology of heterotrophic microflagellates. IV Quantitative occurence and importance as bacterial consumers. Mar. Ecol. Prog. Ser. 9: 35-42

Fenchel, T. (1986). Protozoan filter feeding. Prog. Protistol. 1: $65-113$

Fenchel, T., Jonsson, P. (1988). The functional biology of Strombidium sulcatum, a marine oligotrich ciliate (Ciliophora, Oligotrichina). Mar. Ecol. Prog. Ser. 48: 1-15

Gerritsen, J., Strickler, J. R. (1977). Encounter probabilities and community structure in zooplankton: a mathematical model. J. Fish. Res. Bd. Can. 34: 73-82

Guillard, R. R. (1975). Culture of phytoplankton for feeding marine invertebrate. In: Smith, W. L., Chanley, M. H. (eds.) Culture of marine invertebrate animals. Plenum Press, New York, p. 29-80

Haas, L. W., Webb, K. L. (1979). Nutritional mode of several non-pigmented microflagellates from the York river estuary, Virginia, J. exp. mar. Biol. Ecol. 39: 125-134

Hagström, §. Azam, F., Andersson, A., Wikner, J., Rassoulzadegan, F. (1988). Microbial loop in an oligotrophic pelagic marine ecosystem: possible roles of cyanobacteria and nanoflagellates in the organic fluxes. Mar. Ecol. Prog. Ser. 49: 171-178

Heinbokel, J. F., Beers. J. R. (1979). Studies on the functional role of tintinnids in the Southern California Bight. III. Grazing impact of natural assemblages. Mar. Biol. 52: 23-32

Hobbie, J. E., Daley, R. J., Jasper, S. (1977). Use of Nuclepore filters for counting bacteria by epifluorescence microscopy. Appl. environ. Microbiol. 33: 1225-1228

Ibanez, J. F., Rassoulzadegan, F. (1977). A study of the relationships between pelagic ciliates (Oligotrichina) and planktonic nanoflagellates of the neritic ecosystem of the bay of Villefranche-sur-Mer. Analysis of chronological series. Annls Inst. océanogr., Paris 53: 17-30

Jonsson, P. R. (1986). Particle size selection, feeding rates and growth dynamics of marine planktonic oligotrichous ciliates (Ciliophora: Oligotrichina). Mar. Ecol. Prog. Ser 33: $265-277$

Lessard, E. J., Swift, E. (1985). Species-specific grazing rates of heterotrophic dinoflagellates in oceanic waters, measured with a dual-label radioisotope technique. Mar. Biol. 87. 289-296

McManus, G. B., Fuhrman, J. A. (1986). Bacterivory in seawater studied with the use of inert fluorescent particles. Limnol. Oceanogr. 31: 420-426.
Naitoh, Y., Eckert, R. (1974). The control of ciliary activity in Protozoa. In: Sleigh, M. A. (ed.) Cilia and flagella Academic Press, London, p. 305-352

Rassoulzadegan, F., Gostan, J. (1976). Répartition des ciliés pélagiques dans les eaux de Villefranche-sur-Mer. Remarques sur la dispersion du microzooplancton en mer et à l'intérieur des échantillons dénombrés par la méthode d'Utermöhl. Annls. Inst. océanogr. Paris 52: 175-188

Rassoulzadegan, F. (1978). Dimensions et taux d'ingestion des particules consommées par un tintinnide: Favella ehrenbergü (Clap. et Lachm.) Jörg., cilié pélagique. Annls. Inst. océanogr., Paris 54:17-27

Rassoulzadegan, F. (1982). Feeding in marine planktonic protozoa. Annls. Inst. océanogr., Paris 58 (S): 191-206

Rassoulzadegan, F., Etienne, M. (1981). Grazing rate of the tintinnid Stenosemella ventricosa (Clap. \& Lachm.) Jörg. on the spectrum of the naturally occurring particulate matter from a mediterranean neritic area. Limnol Oceanogr. 26: 258-270

Rassoulzadegan, F., Sheldon, R. W. (1986). Predator-prey interactions of nanozooplankton and bacteria in an oligotrophic marine environment. Limnol. Oceanogr. 31 1010-1021

Rassoulzadegan, F., Laval-Peuto, M., Sheldon, R. W. (1988) Partitioning of the food ration of marine ciliates between pico- and nanoplankton. Hydrobiologia 159: 75-88

Rivier, A., Brownlee, D. C., Sheldon, R. W., Rassoulzadegan, F. (1985). Growth of microzooplankton: a comparative study of bacterivorous zooflagellates and ciliates. Mar. Microb. Food Webs 1: 51-60

Sheldon, R. W., Prakash, A., Sutcliffe, Jr., W. H. (1972). The size distribution of particles in the ocean. Limnol. Oceanogr. 3: 327-340

Sherr, E. B., Rassoulzadegan, F., Sherr, B. F. (1989). Bacterivory by pelagic choreotrichous ciliates in coastal waters of the NW Mediterranean Sea. Mar. Ecol. Prog. Ser. 55: 235-240

Sherr, E. B.. Sherr, B. F. (1987). High rates of consumption of bacteria by pelagic ciliates. Nature, Lond. 325: 710-711

Sherr, B. F., Sherr, E. B., Fallon, R. D. (1987). Use of monodispersed, fluorescently labelled bacteria to estimate in situ protozoan bacterivory. Appl. environ. Microbiol 53: 958-965

Sherr, B. F., Sherr, E. B., Rassoulzadegan, F. (1988). Rates of digestion of bacteria by marine phagotrophic Protozoa: temperature dependence. Appl. environ. Microbiol. 54: 1091-1095

Sherr, E. B., Sherr, B. F. Fallon, R. D., Newell, S. (1986). Small aloricate ciliates as a major component of the marine heterotrophic nanoplankton. Limnol. Oceanogr. 31: $177-183$

Sherr, B. F., Sherr, E. B., McDaniel, J., Gonzalez, J., Hanson, R. (1990). Size selective grazing by bacterivorous protozoa: implications for bacterial production. EOS 71 (2): 162

Sieburth, J. MCN. (1984). Protozoan bacterivory in pelagic marine waters. In: Hobbie, J. E., Williams, P. J. LeB. (eds.) Heterotrophic activity in the sea. Plenum Publishing Corp., New York, p. 405-444

Sieracki, M. E., Haas, L. W., Caron, D. A., Lessard, E. J (1987). The effect of fixation on particle retention by microflagellates: underestimation of grazing rates. Mar. Ecol. Prog. Ser. 38: 251-258

Steedman, H. F. (1976). Zooplankton fixation and preservation. Monographs on Oceanographic methodology. Unesco, Paris

Stoecker, D. K., Guillard, R. R., Kavee, R. M. (1981). Selective predation by Favella ehrenbergii (Tintinnina) on and 
among dinoflagellates. Biol. Bull. mar. biol. Lab., Woods Hole 160: 136-145

Utermöhl, H. (1931). Neue Wege in der quantitativen Erfassung des Planktons (mit besonderer Berücksichtigung des Ultraplanktons). Verh. int theor. angew. Limnol. 5(2): $567-596$

Van Houten, J., Hansma, H., Kung, C. (1975). Two quantitative assays for chemotaxis in Paramecium. J. comp. Physiol. 104: 211-223

Verity, P. G. (1986a). Grazing of phototrophic nanoplankton

This article was presented by Professor T Fenchel, Helsingor, Denmark by microzooplankton in Narragansett Bay. Mar. Ecol. Prog Ser. 29: 105-115

Verity, P. G. (1986b). Growth rates of natural tintinnid populations in Narragansett Bay. Mar. Ecol. Prog. Ser. 29: 117-126

Verity, P. G., Villareai, T. A. (1986). The relative food value of diatoms, dinoflagellates, flagellates, and cyanobacteria for tintinnid ciliates. Arch. Protistenk. 131: 71-84

Wiadnyana, N. N., Rassoulzadegan, F. (1989). Selective feeding of Acartia clausi and Centropages typicus on microzooplankton. Mar. Ecol. Prog. Ser. 53: 37-45

Manuscript first received: December 20,1989

Revised version accepted: April 6, 1990 